\title{
MALARIA PADA KEHAMILAN DAN KONSEKUENSINYA PADA IBU DAN JANIN
}

\author{
Zainabur Rahmah ${ }^{1}$ \\ ${ }^{1}$ Program Studi Pendidikan Dokter Fakultas Kedokteran dan Ilmu-Ilmu Kesehatan \\ Universitas Islam Negeri Maulana Malik Ibrahim Malang \\ E-mail : heryrahmah@yahoo.com
}

\begin{abstract}
ABSTRAK
Malaria merupakan penyakit infeksi yang masih menjadi masalah kesehatan utama di dunia. Malaria menyerang individu tampa membedakan umur dan jenis kelamin tidak terkecuali ibu hamil. Ibu hamil memiliki resiko terserang malaria oleh parasit Plasmodium lebih berat di bandingkan dengan wanita tidak hamil. Ketika seorang hamil akan terjadi supresi imun baik humoral maupun seluler Tujuan makalah ini untuk membahas mekanisme terjadinya malaria pada kehamilan dan konsekuensinya pada ibu dan janin. Adhesi parasit dengan reseptor Chondroitin Sulfate A (CSA) dan Hyaluronic Acid (HA) di plasenta dapat memicu proses inflamasi yang melibatkan sekresi sitokin. Komponen inflamasi yang muncul setelah akumulasi parasit di plasenta berasosiasi dengan patologi imun pada Pregnancy-Associated Malaria (PAM), seperti penebalan membran sitotrofoblas yang mengganggu aliran darah, menghambat transfer IgG melintasi plasenta dan pertukaran nutrisi dari ibu ke janin sehingga terjadi lesi pada plasenta. Selama kehamilan yang terinfeksi malaria terjadi proses cytoadherence di mediasi oleh protein Plasmodium falciparum Erythrocyte Membran Protein-1 (PfEMP-1) dikode oleh gen Var2 ${ }^{\text {CSA }}$ yang mengikat reseptor di plasenta hal ini menyebabkan sekuestrasi eritrosit terinfeksi di sel endotel yang mengakibatkan terjadinya anemia pada ibu sedangkan pada janin menyebabkan berat badan lahir rendah, lahir prematur dan lahir mati.
\end{abstract}

Kata kunci : Malaria, Ibu Hamil, Janin

\begin{abstract}
Malaria is an infectious disease remains a major health problem in the world. Malaria attacks without differentiating individual age and sex of pregnant women are no exception. Pregnant women have a risk of malaria by Plasmodium parasites is more severe in comparison with non-pregnant women. When a pregnancy will occur immunosuppression both humoral and cellular purpose of this paper is to discuss the mechanism of occurrence of malaria in pregnancy and its consequences on the mother and fetus. Parasite adhesion receptors Chondroitin Sulfate A (CSA) and Hyaluronic Acid (HA) in the placenta can trigger an inflammatory process involving the secretion of cytokines. Inflammatory component that appears after the accumulation of parasites in the placenta is associated with immune pathology in the Pregnancy-Associated Malaria (PAM), such as thickening of the membrane cytotrophoblasts that disrupt blood flow, inhibiting the transfer of IgG across the placenta and the exchange of nutrients from mother to fetus, causing lesions in the placenta. Malaria infection during pregnancy is a process of mediation by protein cytoadherence in Plasmodium falciparum erythrocyte membrane protein-1 (PfEMP-1) encoded by genes that bind to receptors on Var2CSA this causes placental sequestration of infected erythrocytes on endothelial cells resulting in anemia in pregnant while on fetus causes low birth weight, premature birth and stillbirth.
\end{abstract}


Key words: Malaria, Maternal, Fetal.

\section{PENDAHULUAN}

Separuh penduduk dunia mempunyai resiko terkena infeksi malaria. Pada tahun 2006 diperkirakan ada 247 juta kasus malaria dengan angka kematian 881000 jiwa. Sekitar 50\% kasus malaria berada di Afrika, sedang sisanya menyebar diseluruh dunia seperti India, Brazil, Afganistan, Srilangka, China dan Indonesia [1]. Penduduk Indonesia berjumlah 230 jiwa diperkirakan 45\% hidup didaerah endemik malaria dan yang terinfeksi malaria sebanyak 2,5 juta jiwa dengan angka kematian sekitar 3480 orang. Kasus infeksi malaria banyak di sebabkan oleh infeksi Plasmodium falciparum [2].

Malaria menyerang individu tanpa membedakan umur dan jenis kelamin, tidak terkecuali wanita hamil yang merupakan golongan rentan. Malaria pada kehamilan dapat disebabkan oleh semua spesies Plasmodium, tetapi sejauh ini Plasmodium falciparum merupakan parasit yang dominan dan mempunyai dampak paling berat terhadap morbiditas dan mortalitas ibu dan janinnya. Pengaruh malaria pada ibu hamil dapat menyebabkan manifestasi klinis seperti anemia dan pada janin menyebabkan bayi lahir prematur, lahir cacat, lahir mati ataupun lahir dengan berat badan rendah [3].

Ibu hamil memiliki resiko terserang malaria oleh parasit Plasmodium lebih berat di bandingkan dengan wanita tidak hamil. Ketika seorang hamil akan terjadi supresi imun baik humoral maupun seluler. Supresi sistem imun selama kehamilan berhubungan dengan keadaan hormonal, konsentrasi hormon progesteron yang meningkat selama kehamilan berefek menghambat aktifasi limfosit T terhadap stimulasi antigen [3].

Selama kehamilan plasenta atau ari-ari yang mempunyai struktur dan fungsi spesifik berfungsi menghubungkan janin dengan uterus sehingga menjamin kehidupan janin. Plasenta yang terdiri-dari vili-vili dan kotelidon berfungsi menyalurkan nutrisi dan oksigen bagi janin, memproduksi berbagai jenis protein dan hormon steroid, juga merupakan jaringan yang mempunyai potensi imun/kekebalan [4].

Selama kehamilan akan terjadi sekuestrasi parasit Plasmodium di plasenta yang mengakibatkan terjadi perubahan suplai nutrisi dan $\mathrm{O}_{2}$ dari ibu kepada janin terhambat, sehingga pertumbuhan janin dalam kandungan mengalami gangguan [5]. Sekuestrasi eritrosit terparasit juga dapat mengaktifkan sinsiotrofoblas dan sel monosit untuk melepaskan sitokin yang berkontribusi akumulasi monosit menyebabkan perubahan fungsi dan pertumbuhan sel plasenta [3].

Fenomena dan mekanisme malaria pada kehamilan sampai sekarang menjadi topik kajian menarik dan memerlukan penelitian dan penjelasan lebih mendalam. Berdasarkan paparan diatas maka penulis akan dibahas tentang malaria pada kehamilan dan konsekuensinya pada ibu dan janin.

\section{TINJAUAN PUSTAKA}

\section{Malaria}

Penyakit Malaria adalah penyakit infeksi yang disebabkan oleh protozoa yang merupakan golongan Plasmodium, yang ditularkan melalui gigitan nyamuk. Di Indonesia ada 46 Spesies nyamuk Anopeles sp dan sekitar 20 spesies yang dapat berperan sebagai vektor penyakit malaria (Gunawan, 2000). Malaria pada manusia disebabkan oleh 5 jenis parasit yaitu Plasmodium falciparum, Plasmodium vivax, Plasmodium malariae, Plasmodium ovale [6] dan Plasmodium knowlesi [7]. 


\section{Epidemiologi Malaria}

Malaria merupakan penyebab utama morbiditas dan mortalitas di seluruh dunia. Data statistik menunjukkan 3.2 milliar manusia di dunia beresiko tertular dengan parasit malaria [8]; [9]. Lebih dari 70\% kasus malaria terjadi di Afrika dan situasi semakin buruk karena penyakit ini terus menyebar ke daerah yang sebelumnya non-endemis 30\% penyakit malaria terkonsentrasi di tujuh Negara meliputi Afrika, India, Brasil, Srilangka, Afganistan, Vietnam dan Kolombia [10]; [1]. Penyebaran kasus malaria ternyata tidak hanya oleh nyamuk Anopheles sp tetapi juga di sebabkan tranfusi darah, jarum suntik, serta dari ibu hamil kepada janinnya [11].

Infeksi malaria sampai saat ini masih merupakan problem klinik di negara-negara berkembang terutama negara yang beriklim tropik. Di Indonesia malaria masih merupakan penyakit infeksi utama di kawasan Timur. Penyakit ini merupakan salah satu masalah kesehatan masyarakat di Indonesia yang mempengaruhi angka kesakitan dan kematian bayi, balita dan ibu hamil [1].

Menurut Survei Kesehatan Rumah Tangga (SKRT) [12], di Indonesia setiap tahunnya terdapat sekitar 15 juta penderita malaria klinis yang mengakibatkan 30.000 orang meninggal tiap tahunnya. Dari data Riset Kesehatan Dasar (RisKesDas) tahun 2007, didapatkan hampir seluruh propinsi di Indonesia merupakan daerah endemis pertumbuhan vektor penyebab penyakit Malaria. Dari 33 propinsi, Papua Barat merupakan propinsi dengan nilai proporsi tertinggi daerah endemis perkembangbiakan vektor penyakit Malaria, disusul kalimantan lalu propinsi Nusa Tenggara Timur [13].

Malaria pada kehamilan merupakan suatu komplikasi yang umum terjadi di daerah endemik malaria khususnya pada primigravida. Angka kematian wanita hamil di daerah malaria unstabil dilaporkan 2-10 kali lebih tinggi di bandingkan wanita yang tidak hamil, sebagian besar kasus malaria pada kehamilan tersebut di hubungkan dengan infeksi Plasmodium falciparum [3].

Setiap tahun dari sekitar 50 juta wanita hamil yang tinggal di daerah endemis malaria diperkirakan 10.000 ribu perempuan dan 200.000 ribu bayi meninggal akibat infeksi malaria selama kehamilan [1]. Ibu hamil dan bayi baru lahir merupakan penderita malaria terburuk karena kedua kelompok ini sangat rentan terhadap infeksi malaria [14].

\section{Biologi dan Siklus Hidup Parasit Malaria}

Plasmodium merupakan parasit subfilum Sporozoa dan family Plasmodida yang menyebabkan penyakit malaria. Plasmodium mempunyai siklus hidup yang kompleks yaitu adanya generasi aseksual (schizogony) yang terjadi dalam tubuh manusia dan generasi seksual (sporogony) yang terjadi dalam tubuh nyamuk betina. Dalam siklus hidup Plasmodium selain ada pergantian generasi (alteration of generation) juga ada pergantian induk semang (alteration of host) [15].

\section{Siklus Hidup Aseksual}

Siklus hidup aseksual terjadi di tubuh manusia. Sporozoit infeksius dari kelenjar ludah nyamuk Anopheles betina di masukkan ke dalam darah manusia melalui ngigitan nyamuk. Dalam waktu tiga puluh menit sporozoit memasuki sel-sel parenkim hati. Di 
dalam sel hati parasit tumbuh menjadi skizon dan berkembang menjadi merozoit. Sel hati yang mengandung parasit pecah dan merozoit keluar dengan bebas, sebagian di fagosit. Karena prosesnya terjadi sebelum memasuki eritrosit maka disebut stadium preeritrositik atau eksoeritrositik [16].

Siklus eritrositik dimulai saat merozoit memasuki sel-sel darah merah. Parasit tampak sebagai kromatin kecil dikelilingi oleh sitoplasma yang membesar, bentuk tidak teratur dan mulai membentuk tropozoit. Tropozoit berkembang menjadi schizon muda, kemudian berkembang menjadi schizon matang dan membelah banyak menjadi merozoit. Selama tahap schizon parasit mengalami replikasi DNA sehingga dalam pembentukannya menghasilkan 8-24 merozoit. Dengan selesainya pembelahan tersebut sel darah merah pecah dan merozoit keluar kemudian memasuki plasma darah. Sebagian parasit memasuki sel darah merah lainnya untuk mengulangi siklus skizogoni. Beberapa merozoit memasuki eritrosit dan membentuk skizon dan parasit lainnya membentuk gametosit untuk persiapan siklus hidup seksual [17] Gambar 1. Siklus Hidup Plasmodium falciparum.

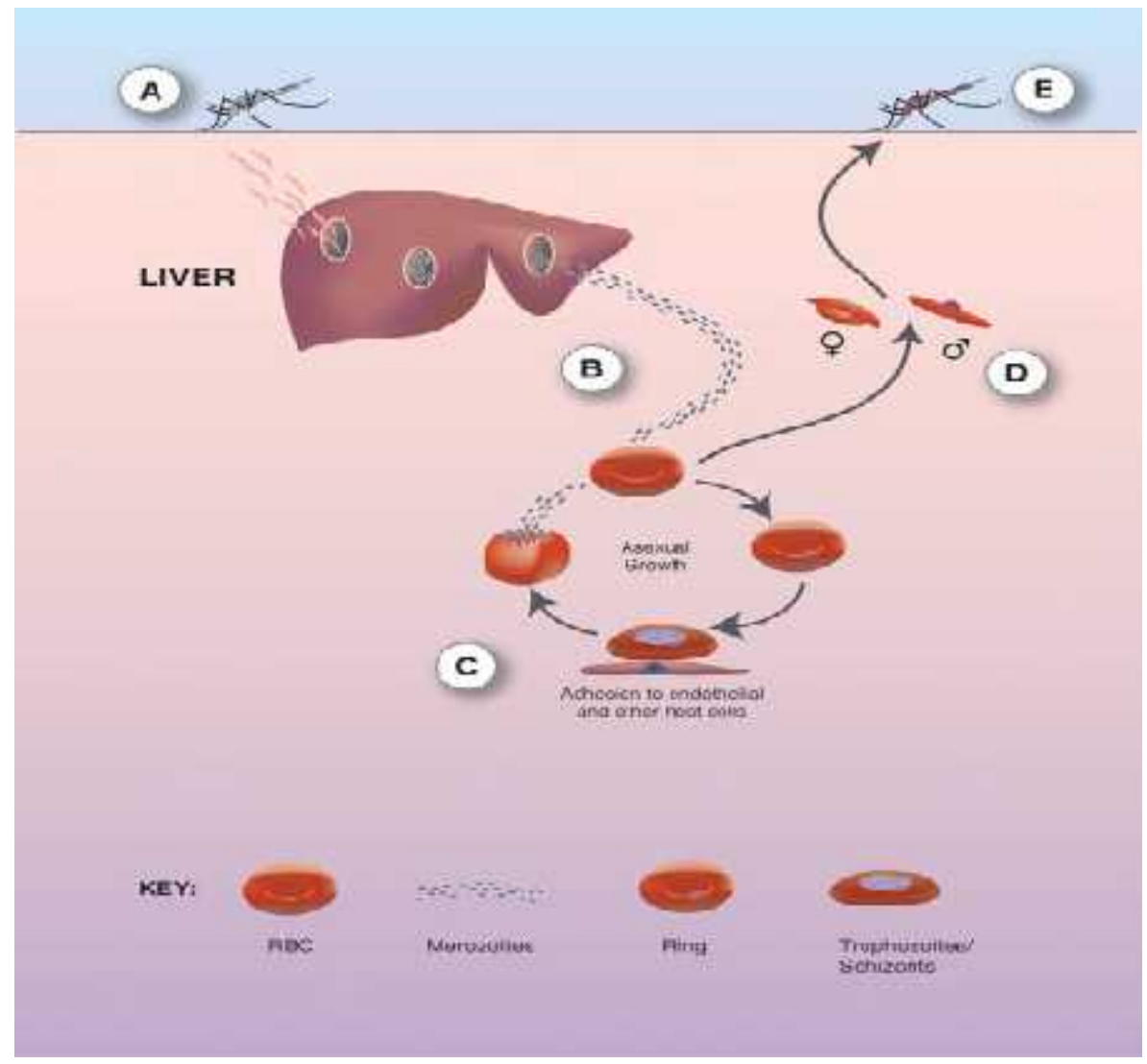

\section{Gambar 1: Siklus Hidup Plasmodium falciparum}

Nyamuk Anopheles menggigit manusia, sporozoit masuk ke aliran darah. Sporozoit menginvasi hepatosit kemudian berkembang menjadi skizon. Skizon ruptur dan melepaskan banyak merozoit. Merozoit yang dilepaskan menginfeksi sel darah merah berkembang menjadi ringform, kemudian trofozoit dan akhirnya menjadi skizon. Skizon ruptur dan melepaskan merozoit. Merozoit ada yang menginfeksi sel darah merah kembali dan ada yang berkembang menjadi gametosit [17].

\section{Siklus Hidup Seksual}


Siklus hidup seksual terjadi di dalam tubuh nyamuk. Proses perkembangan Plasmodium di nyamuk adalah proses yang sangat kompleks. Ketika nyamuk Anopheles sp menghisap darah inang vertebrata yang terinfeksi malaria gametosit masuk ke usus nyamuk. Dalam dua menit gametosit di usus nyamuk berdiferensiasi menjadi gamet jantan dan gamet betina, sesudah itu terjadi fertilisasi kemudian membentuk zigot yang berubah menjadi sebuah ookinet motil. Ookinet keluar dari epitel usus dan aktif di dalam darah. Ookinet menembus epitel usus dengan cara menembus chitin epitel yang kaya dengan peritropic matrix (PM). Selama proses ini ookinet mensekresi enzim kitinase yang dapat memotong kitin dalam peritropic matrix (PM). Selama ookinet menyerang sel epithelium usus, sel ini banyak mengalami apoptosis yang dapat menyebabkan ookinet masuk ke dalam lamina basal dan mencapai lumen usus. Di tempat ini ookinet mengalami transformasi menjadi ookista [18]. Selama perkembangan ookista, parasit tumbuh dan mengalami pembelahan mitosis menghasilkan beribu-ribu sporozoit dan dilepaskan ke hemocoel menuju ke kelenjar ludah (salivary glands) [19]. Gambar 2 menunjukkan siklus hidup Plasmodium di hospes nyamuk.

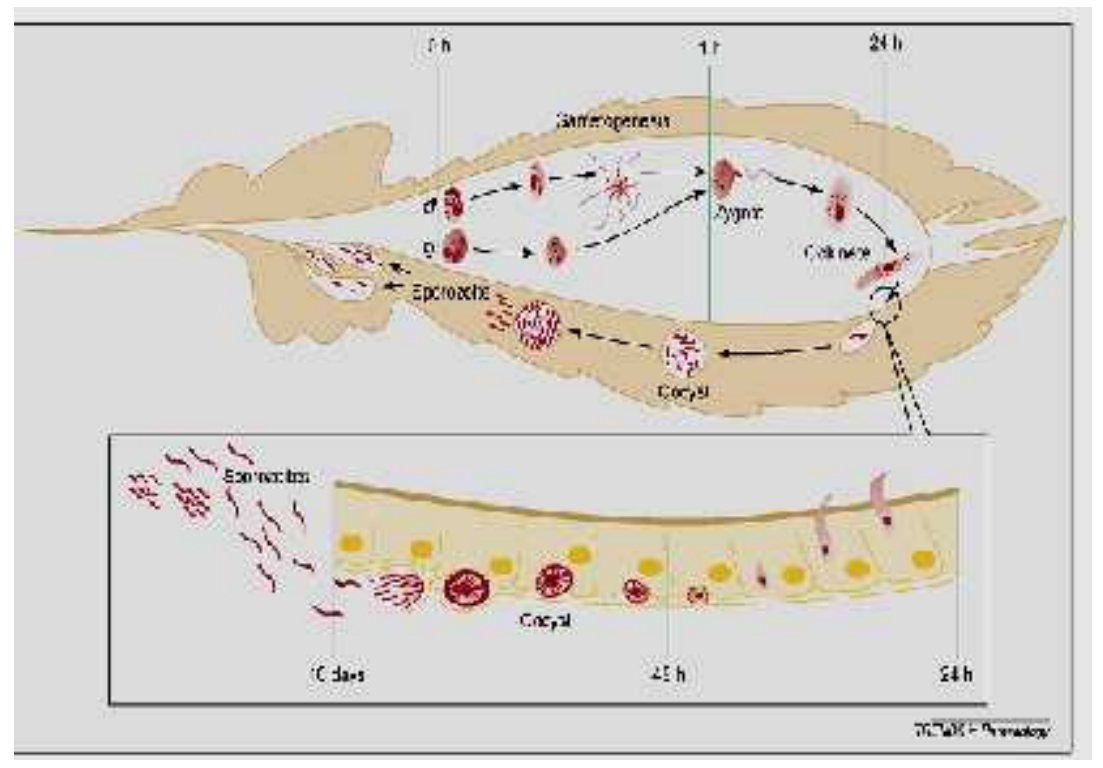

\section{Gambar 2 : Siklus Hidup Plasmodium di Hospes Nyamuk}

Perkembangan seksual Plasmodium terjadi di lumen usus nyamuk dengan cara berdeferensiasi menjadi gamet jantan dan gamet betina, diikuti dengan terjadinya fertilisasi membentuk zigot dan berdeferensiasi menjadi ookinet yang motil. Ookinet menyerang epitel usus.dan terjadi kontak antara lamina basal dan ookinet yang memicu deferensiasi ookinet menjadi ookista. Ribuan sporozoit yang terbentuk di dalam ookista matang dilepaskan ke hemocoel. Sekitar $20 \%$ dari sporozoit dilepaskan menuju kelenjar ludah dan ditularkan ketika nyamuk kontak dengan individu lain [19].

\section{PEMBAHASAN}

\section{Patologi dan Patomekanisme Infeksi Malaria pada Kehamilan}

Patogenesis malaria dipengaruhi oleh faktor parasit, hospes dan lingkungan. (1) faktor parasit adalah intensitas transmisi berpengaruh terhadap derajat parasitemia, densitas parasit sangat berhubungan dengan morbiditas dan mortalitas akibat malaria, dan 
virulensi parasit yang ditentukan oleh kemampuan untuk mengadakan perlekatan dengan sel lain. (2) faktor hospes adalah endemisitas, umur, status gizi, dan status imunologi. (3) faktor lingkungan seperti suhu, kelembaban dan curah hujan yang mendukung dalam penyebaran malaria (WHO, 2005). Parasit dalam eritrosit akan mengalami 2 stadium yaitu stadium cincin pada 24 jam pertama dan stadium matur pada 24 jam kedua. Permukaan parasit dalam eritrosit stadium cincin akan menampilkan antigen Ring Erytrocite Surface Antigen (RESA) yang menghilang setelah parasit masuk stadium matur. Permukaan parasit dalam eritrosit stadium matur akan mengalami penonjolan dan membentuk knob dengan Histidin Rich Protein-1 (HRP-1) sebagai komponen utamanya kemudian parasit dalam eritrosit melepaskan toksin malaria berupa glikosilfosfatidilinositol (GPI) yang merangsang pelepasan TNF- $\alpha$ dan IL-1 dari makrofag [20]. Gambar 3. Parasit dalam eritrosit.

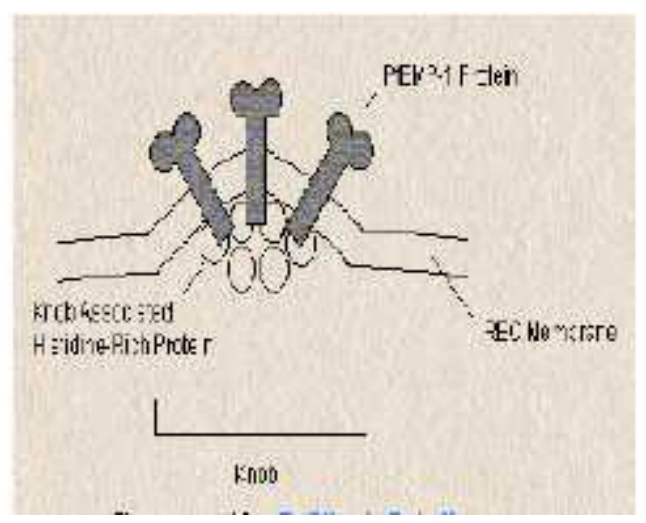

\section{Gambar 3. Parasit dalam Eritrosit}

Parasit dalam eritrosit akan mengalami penonjolan dan berbentuk knob yang berisi Plasmodium falciparum Erythrocyte Membran Protein-1 (PfMP-1) yang berasosiasi dengan Histidine Rich-protein-1 (HRP-1) [20].

Di dalam sel darah merah parasit mencerna protein terutama hemoglobin yang dalam metabolismenya membentuk pigmen disebut hemozoin. Setelah parasit Plasmodium falciparum menginfeksi sel eritrosit maka protein diekspresikan kepermukaan eritrosit yang dapat mengubah konformasi sel inang dan menghasilkan elektron yang strukturnya padat disebut knob. Knob berisi Plasmodium falciparum erythrocyte membrane protein 1 (PfEMP-1) bertindak sebagai penentu cytoadherence pada sel endotel pembuluh darah [21].

Infeksi malaria oleh Plasmodium falciparum sering menyebabkan komplikasi pada beberapa organ seperti otak, paru, ginjal dan gastroinstestinal karena adanya anoksia mikrovaskuler pada jaringan tersebut [22]. Anoksia jaringan terjadi karena adanya penyumbatan pembuluh darah di mikrovaskuler, akibat adanya proses cytoadherence, rosetting dan sekuestrasi [23].

Cytoadherence adalah melekatnya eritrosit terparasit dipermukaan endotel vaskuler. Terjadinya cytoadherence pada penyakit malaria karena adanya perlekatan antara eritrosit yang terinfeksi Plasmodium stadium lanjut dengan sel endotel pembuluh kapiler (endothelial cytoadherence). Cytoadherence terjadi akibat interaksi molekuler dari ligan Plasmodium falciparum Erythrocyte Membrane Protein-1 (PfEMP-1) dengan reseptor yang terdapat pada membran sel endotel seperti Intercellular Adhesion Melecule-1 
(ICAM-I) reseptor pada otak, Cluster of Differentiation-36 (CD-36) yang merupakan reseptor pada mivrovascular dan Chondroitin Sulfate A (CSA) dan Hyaluronic Acid (HA) pada sel plasenta. Cytoadherence mengakibatkan kerusakan pembuluh darah kapiler dan menghambat aliran darah ke pembuluh darah kapiler akhir karena terbentuk rosett dan sekuestrasi [24]; [25].

Rosetting adalah perlekatan antara eritrosit berparasit matang yang diselubungi sekitar 10 atau lebih eritrosit non parasit sehingga berbentuk seperti bunga. Rosetting berperan dalam terjadinya obstruksi aliran darah jaringan sehingga mempermudah terjadinya cytoadherence. Salah satu faktor yang mempengaruhi terjadinya rosetting adalah golongan darah dimana terdapatnya antigen golongan darah A dan B yang bertindak sebagai reseptor pada permukaan eritrosit yang tidak terinfeksi parasit [26].

Sekuestrasi timbul akibat dari eritrosit matang yang tinggal dalam jaringan mikrovaskular. Plasmodium falciparum yang hanya mengalami sekuestrasi, hal ini dikarenakan pada Plasmodium lain seluruh siklus terjadi pada pembuluh darah perifer. Sekuestrasi tertinggi terdapat di otak diikuti dengan hepar dan ginjal bertujuan untuk menghindari clearance oleh limfa dan bersembunyi dari sistem imun. Sekuestrasi ini diduga memegang peranan utama dalam patofisiologi malaria berat [27].

Wanita hamil yang terinfeksi malaria mengembangkan antibodi yang menghambat binding eritrosit terinfeksi pada Chondroitin Sulfate A (CSA), antibodi ini berhubungan dengan perlindungan terhadap infeksi malaria pada plasenta. Ibu primigravida memiliki kerentanan jauh lebih tinggi terinfeksi malaria daripada multigravida. Hal ini disebabkan karena antibodi yang diperoleh setelah kehamilan multipel menyebabkan pengurangan jumlah eritrosit terinfeksi mengalami sekuestrasi di plasenta sehingga mengurangi keparahan pada kehamilan berikutnya [28]. Gambar 4 binding eritrosit terinfeksi pada endotel microvaskuler dibandingkan di plasenta.

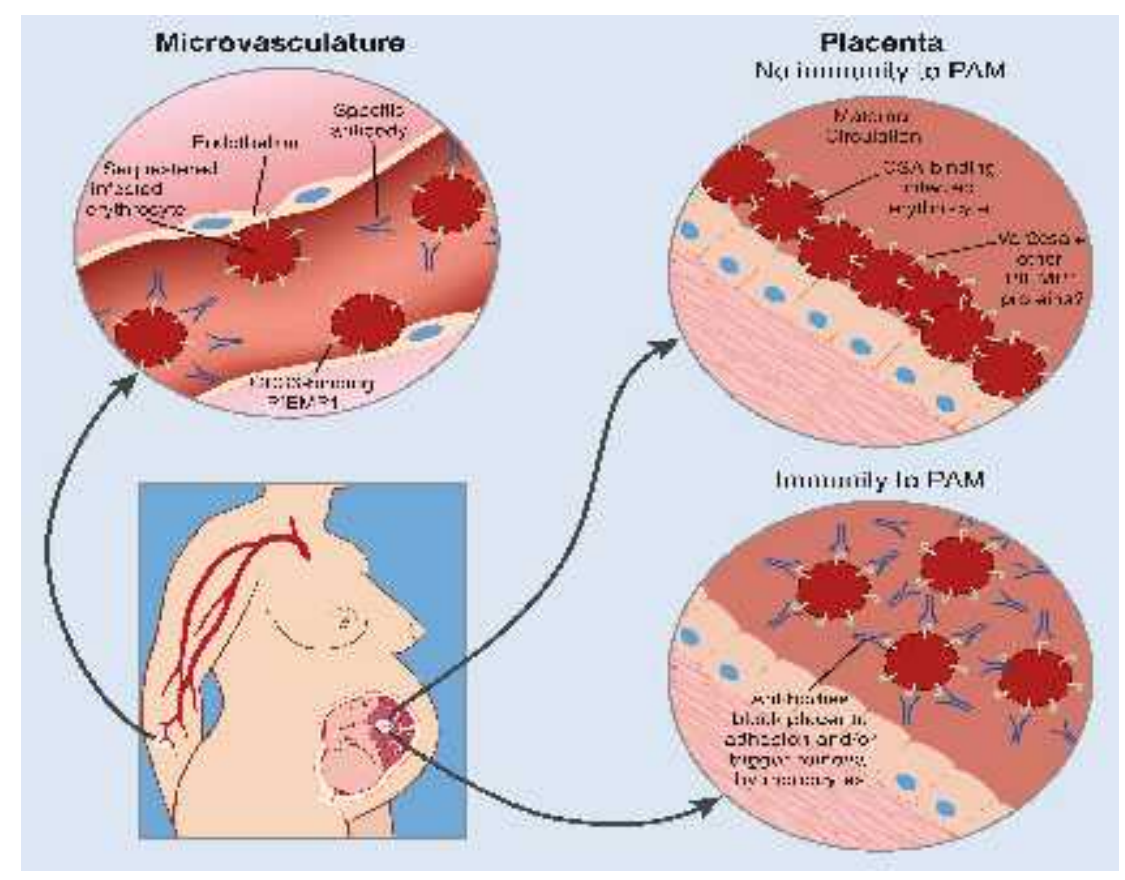

Gambar 4. Binding Eritrosit Terinfeksi pada Endotel Microvaskuler Dibandingkan di Plasenta. 
Wanita hamil, terutama ibu yang pertama kali hamil, rentan terhadap sekuestrasi eritrosit terinfeksi di dalam plasenta. Isolat plasenta secara antigenik dan fungsional berbeda. Pada mikrovaskuler terdapat reseptor CD-36 dan di plasenta terdapat reseptor Chondroitin Sulfate A (CSA ). Selama hamil, wanita meghasilkan antibodi ke permukaan eritrosit yang terinfeksi dapat menghalangi binding eritrosit terinfeksi ke plasenta atau dektruksi oleh monosit. Sehingga mengurangi keparahan pada kehamilan berikutnya [28].

Selain Chondroitin Sulfate A (CSA) juga terdapat Hyaluronic Acid (HA) yang merupakan reseptor pada plasenta. Penelitian [29], melakukan tes tentang cytoadherence di plasenta yang terinfeksi parasit pada 60 ibu hamil di Tanzania menunjukkan bahwa hampir semua parasit terikat dengan reseptor CSA dan hanya 3 orang dengan HA.

Adhesi parasit dengan reseptor CSA dan HA di plasenta dapat memicu proses inflamasi yang melibatkan sekresi sitokin di sel mononuklear. Komponen inflamasi yang muncul setelah akumulasi parasit di plasenta berasosiasi dengan patologi imun pada Pregnancy-Associated Malaria (PAM), seperti penebalan membran sitotrofoblas. Proses inflamasi ditandai dengan terjadinya ngangguan aliran darah, menghambat transfer IgG melintasi plasenta dan pertukaran nutrisi dari ibu kejanin sehingga terjadi lesi pada plasenta [25].

Mekanisme pengendalian parasitemia di plasenta didasarkan pada antibodi memblock/menghalangi adhesi eritrosit terinfeksi binding dengan CSA. Penelitian [30], mempelajari 198 wanita hamil di Kamerun dan menunjukkan bahwa ibu multigravida mulai memberikan respon imun berbasis antibodi setelah 12 minggu kehamilan, sedangkan primigravida 20 minggu lebih lama untuk mengembangkan adhesi seperti antibodi memblokade adhesi eritrosit terinfeksi di plasenta.

Antibodi cytophilic telah dikumpulkan pada wanita hamil yang terinfeksi malaria. Mekanisme seperti fagositosis dan aktivasi komplemen juga dapat membantu melindungi kehamilan yang terinfeksi malaria [25]. [31], menunjukkan bahwa immunoglobulin G1 (IgG1) dan immunoglobulin G3 (IgG3) adalah subclass paling umum pada kehamilan terinfeksi malaria. Jumlah antibodi ini lebih besar ditemukan pada ibu hamil multipara.

Fungsi antibodi selama kehamilan adalah menghambat adhesi parasit pada CSA di plasenta juga mengopsonisasi eritrosit terinfeksi untuk berinteraksi dengan reseptor Fc pada sel fagosit sehingga mempromosikan clearance parasit dan pelepasan mediator inflamasi [32].

\section{Repon Imun Terhadap Infeksi Malaria Selama Kehamilan}

Selama kehamilan normal toleransi ibu terhadap janin dijelaskan oleh dominansi sitokin Th2 dengan mengesampingkan sitokin tipe Th1 sehingga melindungi janin dari rejeksi ibu. Namun, dominansi imunitas Th2 juga dilaporkan pada kejadian abortus, oleh karena itu paradigma Th1/Th2 tidak cukup untuk menjelaskan mengapa janin tidak ditolak oleh sistem imun ibu dan sekarang paradigma diganti dengan Th1/Th2/Th17 dan $\mathrm{T}$ regulatory (Treg) [33]. Th17 menghasilkan sitokin IL-17 yang bersifat proinflamasi yang memainkan peran penting pada induksi inflamasi dan diperlukan pada awal kehamilan untuk proses implantasi. Sel Treg mengatur inflamasi di uterus pada waktu terjadi implantasi. Inflamasi yang berlebihan menyebabkan janin mengalami aborsi. Hubungan timbal balik antara sel Th17 dan sel Treg di daerah perifer dan desidua dapat menyebabkan terjadinya aborsi. Interleukin 6 merupakan sitokin yang menghambat perkembangan sel Treg dan menginduksi diferensiasi Th17. Peningkatan IL-1 dan IL-6 dan penurunan 
produksi TGF- $\beta$ menyebabkan peningkatan IL-17 dan penurunan sel Treg di dalam rahim [34].

Selama malaria plasenta, akumulasi eritrosit terinfeksi dapat menstimulasi pelepasan sitokin Th1 seperti TNF- $\alpha$ oleh makrofag yang membantu membersihkan plasenta dari parasit malaria melalui peningkatan aktifitas fogositosis dan oleh produksi Reactive Oxygen Species (ROS) dan metabolit Nitric Oxide (NO) [35]. Respon sitokin Th1 yang kuat selama malaria plasenta dapat menyebabkan anemia pada ibu, abortus spontan pada janin dan lahir prematur. Konsentrasi TNF- $\alpha$ di darah perifer lebih rendah dibandingkan di darah plasenta. Peningkatan TNF- $\alpha$ dapat meningkatkan cytoadherence eritrosit terinfeksi di plasenta [36]. Interferon- $\gamma$ juga meningkat di ruang intervilous pada malaria plasenta. Sitokin IFN- $\gamma$ dihasilkan oleh limfosit ibu dan trofoblas janin. Kehadiran parasit malaria di plasenta memicu trofoblas untuk menghasilkan IFN- $\gamma$ yang berfungsi melindungi janin dari infeksi mikroorganisme yang mampu melintasi barier plasenta [37].

Selama malaria plasenta Migration inhibitory factor (MIF) disekresikan oleh sinsiotrofoblas janin sebagai akibat eritrosit terinfeksi mengikat CSA di plasenta. Migration inhibitory factor (MIF) merangsang fagositosis eritrosit terinfeksi juga mendorong akumulasi makrofag di plasenta [38]. Konsentrasi MIF lebih tinggi pada ibu hamil primigravida dari pada multigravida disebabkan karena kadar steroid pada primigravida lebih tinggi, oleh karena itu peningkatan konsentrasi MIF dapat memberikan perlindungan pada plasenta [39].

Eritrosit yang terinfeksi Plasmodium falciparum akan mengalami sekuestrasi di plasenta dan merangsang akumulasi sel mononuclear ibu. Penelitian yang dilakukan [40], yang menggunakan kultur su leukosit yang di ambil di ruang intervillous plasenta terinfeksi malaria menunjukkan bahwa sitokin IL-10 sekresinya lebih tinggi dari pada kultur yang menggunakan plasenta yang tidak terinfeksi malaria.. Produksi IL-10 meningkat karena efek imunoregulatornya yang menekan dominansi Th1 pada malaria plasenta. Tingginya IL-10 di malaria plasenta berasosiasi dengan terjadinya anemia pada ibu dan janin mengalami lahir prematur [40]. Tabel 2 menunjukkan fungsi kemokin dan sitokin selama malaria plasenta

\section{Komplikasi Akibat Infeksi Terhadap Ibu dan Janin}

Berbagai komplikasi dapat ditimbulkan oleh infeksi malaria pada kehamilan. Anemia sangat sering terjadi pada ibu hamil yang terinfeksi malaria. Pada janin dapat terjadi berat badan lahir rendah, Intarutrine growth retardation, lahir mati dan abortus [41].

\section{Pengaruh Infeksi Malaria pada Ibu Hamil}

Anemia merupakan gejala yang sering dijumpai pada infeksi malaria. Diwilayah endemis anemia sering dijumpai pada ibu hamil. Mekanisme terjadinya anemia meliputi 1). Pembersihan (Clearence) atau dekstruksi sel darah yang terinfeksi 2). Pembersihan (clearance) sel darah merah yang tidak terinfeksi 3). Terjadinya supresi eritropoitik dan disentropoisis. Terjadinya anemia pada prinsipnya dijelaskan sebagai berikut : selama infeksi malaria terjadi dekstruksi sel darah yang terinfeksi dan sel darah yang tidak terinfeksi di limpa. Aktivitas dan jumlah makrofag juga meningkat selama infeksi malaria, karena itu berkontribusi pada penghancuran sel darah yang tidak terinfeksi. Produk Parasit seperti Ring Surface Protein 2 (RSP-2) yang menjadi bagian dari antigen imunoglobulin kompleks disimpan pada sel darah merah yang terinfeksi. Protein ini diekpresikan setelah invasi merozoit kedalam sel darah merah memediasi eritrosit terinfeksi ke sel endotel. Ring 
Surface Protein 2 (RSP-2) juga di simpan pada sel darah merah yang tidak terinfeksi sehingga terjadi opsonisasi pada sel darah tersebut. Keadaan anemia semakin diperberat dengan adanya supresi pada sumsum tulang sehingga menghambat eritropoisis yang disebabkan oleh peningkatan TNF- $\alpha$ [17]. Dengan demikian proses terjadinya anemia pada infeksi malaria merupakan proses yang multi faktorial (Gambar 5).

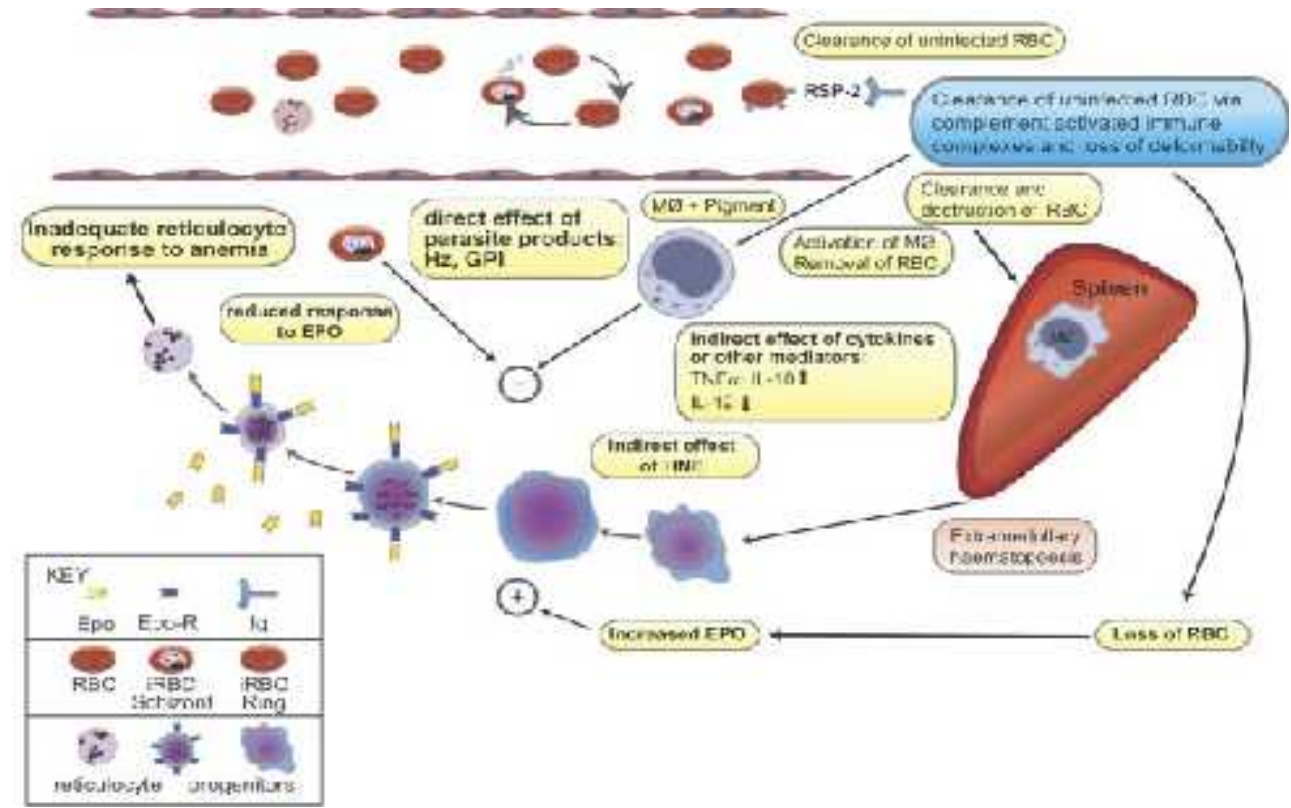

\section{Gamabr 5. Efek Langsung dan tidak Langsung dari Parasit Terhadap Terjadinya Anemia pada Malaria.}

Anemia malaria ditandai oleh kerusakan sel darah merah yang terinfeksi, terjadi perubahan dalam komposisi protein membran dan mengakibatkan kompleks imun sel darah merah, Ag, dan imunoglobulin (Ig) (misalnya, RBC: RSP2: Ig) yang dibersihkan oleh makrofag dan limpa. makrofag yang mengandung pigmen parasit dapat melepaskan sitokin dan mediator inflamasi biologis aktif lainnya seperti hidroksi-nonenal (HNE). Ada kemungkinan bahwa pigmen malaria memiliki efek penghambatan langsung pada eritropoiesis [17].

Keterangan : Epo : Erythropoietin; Epo-R : Erythropoietin Receptor; M: Macrophage; RSP-2: Ring Surface Protein-2;Ig: Immunoglobulin

Pembesaran limpa biasanya teraba 3 hari setelah serangan infeksi akut. Limpa merupakan organ yang penting untuk pertahanan tubuh melawan infeksi malaria. Limpa mengeliminasi eritrosit terinfeksi melalui mekanisme imun dan pengenalan perubahan deformabilitas, .pada gambaran jaringannya di dapatkan eritrosit terinfeksi melekat pada makrofag melalui knob permukaan karena terjadi fagositosis aktif. Adanya retensi eritrosit terinfeksi maupun yang tidak terinfeksi, peningkatan fagositosis oleh mononuclear limpa dan lisis yang dimediasi complement-fixing malaria antigen-antibody menyebabkan hipertrofi RES (Reticuloenothelial System) [41].

Terjadinya anemia pada ibu hamil yang terinfeksi malaria di perparah dengan adanya cytoadherence sel darah merah terinfeksi di endotel plasenta. Selain itu cytoadherence mengakibatkan dinding pembuluh darah kapiler mengalami kerusakan karena terbentuk sekuestrasi dan rosetting, proses tersebut menyebabkan terjadinya edema dan hipoksia karena adanya kebocoran kapiler dan berkurangnnya aliran darah. Sekuestrasi eritrosit terinfeksi Plasmodium dalam intervillous plasenta mengakibatkan perubahan 
suplai nutrisi dan oksigen dari ibu ke janin terhambat. Sehingga menyebabkan berat badan lahir rendah. Intrauterine growth retardation (IUGR) dan lahir mati [42].

\section{Pengaruh Infeksi Malaria pada Janin}

Perkembangan janin dalam kandungan dibagi menjadi 3 tahap. Tahap pertama periode janin mengalami organogenesis, tahap kedua janin mengalami pertumbuhan dan tahap ketiga adalah tahap fetus ditandai dengan pertumbuhan tubuh yang cepat dan penyempurnaan sistem organ. Selama kehamilan yang terinfeksi malaria terjadinya angka kematian perinatal lebih tinggi pada bayi lahir dengan IUGR. Resiko terjadinya IUGR meningkat jika infeksi termasuk varian multialelic kompleks yang terjadi pada trimester kedua bukan trimester ketiga [36].

Selama malaria plasenta terjadi sekresi sitokin proinflamasi seperti TNF- $\alpha$ berasosiasi secara konsisten dengan terjadinya janin mengalami berat badan lahir rendah baik melalui IUGR yang berhubungan dengan konsentrasi tinggi akumulasi monosit di plasenta maupun melalui lahir prematur [17].

Terjadinya bayi lahir prematur disebabkan karena tingginya kadar IL-10 di plasenta. Tingginya kadar Interleukin-10 juga dapat menyebabkan anemia pada ibu. Anemia pada ibu yang berhubungan dengan malaria plasenta berkorelasi dengan akumulasi pigmen monosit dan makrofag di plasenta. Stress oksidatif menghasilkan tingginya kadar TNF- $\alpha$ yang menyebabkan mengubah membran eritrosit yang mengarah kepada penghancuran eritrosit,juga mensupresi eritropoisis, akibatnya mengakibatkan anemia pada ibu [43].

Terjadinya aborsi spontan dikaitkan dengan tingginya kadar sitokin Th1 seperti TNF- $\alpha$ pada plasenta yang terinfeksi malaria. Tumor necrosis factor $\alpha$ menyebabkan nekrosis pada janin dan meningkatkan resiko terjadinya kontraksi rahim sehingga mengakibatkan janin mengalami aborsi [3]. Selain itu IFN- $\gamma$ dapat menginduksi dan mengaktifkan sel natural killer yang ditemukan pada darah perifer perempuan yang mengalami aborsi [44].

\section{KESIMPULAN}

- Terjadinya malaria plasenta di sebabkan akumulasi eritrosit terinfeksi di daerah intervillous plasenta

- Selama kehamilan yang terinfeksi malaria akan terjadi cytoadherence eritrosit terinfeksi oleh Plasmodium. Terjadinya cytoadherence di mediasi oleh protein Plasmodium falciparum Erythrocyte Membran Protein-1 (PfEMP-1) dikode oleh gen Var2 ${ }^{\mathrm{CSA}}$ yang mengikat reseptor Chondroitin Sulfate A (CSA) dan Hyloronic Acid (HA) di plasenta.

- Infeksi malaria selama kehamilan akan mengakibatkan sekuestrasi eritrosit di plasenta pada daerah intervilous sehingga menyebabkan perubahan suplai nutrisi dan oksigen terhambat yang mengakibatkan terjadinya anemia pada ibu sedangkan pada janin menyebabkan berat badan lahir rendah, lahir prematur dan lahir mati.

- Selama kehamilan yang terinfeksi malaria terjadi akumolasi leukosit di ruang intervilous yang mensekresikan IL-10 lebih tinggi pada kehamilan normal dampaknya pada ibu anemia sedangkan pada janin lahir prematur. 


\section{DAFTAR PUSTAKA}

[1] World Health Organization. 2008. The Malaria Report. http; www.who.int/malaria/wmr2008/malaria

[2] Departeman Kesehatan RI. 2008. Data Daerah Endemik Indonesia: http://www.ppmplp.depkes.go.id/images.m1_s2_i192_b.pdf.

[3] Rogerson SJ;Hviid. L; Duffy.PE. 2007. Malaria in Pregnancy: Pathogenesis and Immunity. Lancent zintect Dis: 105-17,Vol.7.

[4] Bowen JA. 2000. The role of integrins in reproduction. Proc Soc Exp Biol Med. 223(4): 31-43

[5] Ndam and Deloron. 2007. Review Article Molecular Aspects of Plasmodium falciparum Infection During Pregnancy. Hindawi Publishing Corporation Journal of B of iomedicine and Biotechnology. 13(10):1155.

[6] Frevert, U and Nurdin E. 2005. Arrest in the Liver-Genetically Defined Malaria Vaccine? Clinical Implication of Basic Research. N.Engl.J. Med. (352).

[7] Korenromp, E.L., Williams, B.G., Gouws, E., Dye, C. \& Snow, R.W. 2003. Measurement of Trends in Childhood Malaria Mortality in Africa: an Assessment of Progress Toward Targets Based on Verbal autopsy. Lancet Infectious Diseases 3, 349-58.

[8] World Health Organisation. 2005. World Malaria Report 2005. http://www.who.int,malaria.html.

[9] Pijnenborg, R., Vercruysse, L., Hanssens, M. 2006. The Uterine Spiral Artery in Human Pregnancy Facts and Controversies. Placenta. 27:939-958.

[10] Davis, R. 2002. History of Malaria. RPH Lab. Medicine. http:// www. wa.gov.au/labs/haem/malaria/history.htm \#op.

[11] Departeman Kesehatan RI. 2005. Data Daerah Endemik Indonesia: http://www.ppmplp.depkes.go.id/images.m1_s2_i192_b.pdf

[12] Departeman Kesehatan RI. 2008. Data Daerah Endemik Indonesia: http://www.ppmplp.depkes.go.id/images.m1_s2_i192_b.pdf

[13] CDC (Center for Disease Control and Prevention). 2006. Schema of The Life Cycle of Malaria. National for Infectious Diseases, Dvision of Parasitic Diseases, Division of Parasitic Diseases. http://www.cdc.gov/Malaria/biology/life_cycle.htm (online).

[14] Garcia JE; Puentes A and Patarroyo ME. 2006. Developmental Biology of Sporozoite-Host Interactions in Plasmdium falciparum Malaria: Implications for Vaccine Design. Clin. Micro. Rev. Oct :686-707

[15] Vignali M; Speake C; Duffy PE. 2009. Malaria sporozoite proteome leaves a trail. Genome Biology, 10:216 (doi:10.1186/gb-2009-10-4-216).

[16] Laminkara AA; Brown D; Potocnik A. 2007. Malaria Anemia: On Mice and Man. Blood, 110:18-28.

[17] Abraham EG and Jacobs-Lorena M. 2004. Mosquito Midgut Barriers to Malaria Parasite development. Insect Biochem Mol Biol. 34(7): 667-671.

[18] Ghosh A, Srinivasan P, Abraham EG, Fujioka H and Jacobs-Lorena M..2003. Molecular Strategies to Study Plasmodium-mosquito Interactions. Trends Parasitol. 19(2):94-101.

[19] Whlgren and Perlman. 2005. Malaria Melecular and Clinical Aspects. Taylor and Francis e-Library Amsterdam The Netherlands. 
[20] Costa F. TM; Lopes S. CP; Ferrer M; Leite JA; Jaular LM; Bernabeu M; Nogueira PA; Mourao M.PG; Becerra. CF; Nogueira PA; Portillo, H. 2011. On Cytoadhesion Plasmodium Vivax; Raison D'etre ?. Mem Inst Oswaldo Cruz. Rio de oswaldo, Cruz. Rio de Janeiuro. Vol. 106(Suppl)

[21] Miller LH; Baruch DI; Marsh K; Doumbo OK. 2002. The Pathogenic Basis of Malaria.Nature. (415); 673-679.

[22] Miller LH; Baruch DI; Marsh K; Doumbo OK. 2002. The Pathogenic Basis of Malaria.Nature. (415); 673-679.

[23] Kirchgatter, K; Portillo, H.A. 2005. Clinical and Moleculer spect of Severe Malaria. Anais da Academia Brasileira de Ciencias. 77(3): 455-475.

[24] Costa F,TM; Lopes S, CP; Ferrer M; Leite J,A; Jaular, Lorena Martin; Bernabeu M; Nogueira P, A; Mourao P, G; Becerra Fernandez, C; , RioLacerda M, VG; Avril M; Nogeira; Gysin, J. 2006. Cytoadhesion of Plasmodium falciparum-Infected Erythrocytes and the Infected Placenta : a Two-Way Patway. Brazilian Journal of Medical and Biological Research. 39:1525-1536.

[25] Christine M; Cserti; Walter H; Dzik. 2007. The ABO blood group system and Plasmodium falciparum malaria. Blood October 1;110(7):2250-2258. Full text at http://bloodjournal.hematologylibrary.org/content/110/7/2250.long

[26] Miller LH; Baruch DI; Marsh K; Doumbo OK. 2002. The Pathogenic Basis of Malaria.Nature. (415); 673-679.

[27] Chaouat, G., Le'de'e-Bataille, N., Zourbas, S., Ostojic, S., Dubanchet, S., Martal, J., Frydman, R., 2003. Cytokines, Implantation and Early Abortion: Re-examining the Th1 /Th2 Paradigm Leads to Question the Single Pathway, single therapy concept. Am J Reprod Immunol. 50:177-186.

[28] Smith J.D; Deitsch K.W. 2004. Pregnancy-associated Malaria and the Prospects for Syndrome-specific Antimalaria Vaccines. Published November 1, 2004 // JEM vol. 200 no. 9 1093-1097.

[29] Beeson, JG; Osier , H.H.A; Engwerda, CR. 2008.Recent Insights Into Humoral and Cellular Immune Responses Against Malaria. Review. J. Parasitol. 38,S17-S98.

[30] O’Neil-Dunne I; Achur RN; Agbor-Enoh ST; Valiyaveettil M; Naik RS; Ockenhouse CF. 2001. Gravidity-Dependent Production of Antibodies that Inhibit Binding of Plasmodium falciparum-Infected Erythrocytes to Placental Chondroitin Sulfate Proteoglycan During Pregnancy. Infect Immun; 69:7487-7492.

[31] Megnekou R; Staalsoe T; Taylor DW; Leke R; Hviid L. 2005. Effects of Pregnancy and Intensity of Plasmodium falciparum Tranmissin on Immonoglobulin G Sublass Responses to Variant Surface Antigens. Infect Immun. 73:4112-4118.

[32] Elliott SR; Duffy MF; Byrne TJ; Beeson JG; Mann EJ; Wilson DW. 2005. CrossReactive Surface Epitopes on Chondroitin Sulfate A-Adherent Plasmodium falciparum-infected Erythrocytes are Associated with Transcription of var2csa, Infect Immun: 73:2848-2856.

[33] Saito.S; Nakashima. A; Shima T; Ito M. 2010. Th1/Th2/Th17 and Rgulatory T-Cell Paradigm in Pregnancy. Am J Reprod Immunol; 63;601-610.

[34] Arruvito, L., Sanz, M., Banham, A.H., Fainboim, L. 2007. Expansion of CD4+CD25+ and FOXP3+ Regulatory T Cells During the Follicular Phase of the Menstrual Cycle: Implications for Human Reproduction. J Immunol. 1(78) : 2572 2578.

[35] Suguitan AL; Rose Jr; Leke, GF; Fouda G; Zhou A; Thuita L; Melenou S; Fogako J; 
Megnekou R; Taylor. 2003a. Changes in The Levels of Chemokines and Cytokines in the Placentas of Women with Plasmodium falciparum. The Journal of Infections Diseases: 188: 1074-82.

[36] Kane EG; Andrew W; Taylor-Robinson. 2011. Prospects and Pitfalls of PregnancyAssociated Malaria Vaccination Based on the Natural Immune Response to Plasmodium falciaprum Var2CSA-Expressing Parasites

[37] Mens PF; Bojtor EC; Henk DFH; Schalling. 2010. Moleculer Interactions in The Placenta During Malaria Infection. European Journal af Obstetrics and Gynecology and Reproductive Biology 152.126-132.

[38] Chaisavaneeyakorn, S., Moore, J.M., Othoro, C. 2005. Immunity to Placental Malaria. IV. Placental is Associated with Up-regulation of Macrophage Migration Inhibitory Factor in Intervilous Blood.J Infect Dis. 186:1371-5.

[39] Chaouat, G., Le'de'e-Bataille, N., Zourbas, S., Ostojic, S., Dubanchet, S., Martal, J., Frydman, R., 2003. Cytokines, Implantation and Early Abortion: Re-examining the Th1 /Th2 Paradigm Leads to Question the Single Pathway, single therapy concept. Am J Reprod Immunol. 50:177-186.

[40] Suguitan AL; Cadigan TJ; Nguyun TA. 2003b. Malaria-associated Cytokine Changes in the Placental of Women with Pre-term Deliveries in Yaounde. Cameroon. Am J Trop Med Hyg;69:574-81.

[41] Armorsolo L; Suguitan Jr; Timothy JC; Thu AN; Zhou A; Robert JIL; Metenou S; Thuita L; Megnekou R; Fogako J; Rose GFL; Taylor DW. 2003. MalariaAssociated Cytokine Changes In the Plasenta of Women With Pre-term Deliveries in yaounde. Cameroon, Am.J.Trop. Med. Hyg, 69 (6) :574-581.

[42] Neres R. Marinho C.R.F; Goncalves L.A; Catarino M B; Penha-Goncalves. 2007. Pregnancy Outcome and Placenta Pathology in Plasmodium berghei ANKA Infected Mice Reproduce the Pathogenesis of Severe Malaria in Pregnant Women. PLOS ONE 3(2): e1608. Doi:10.1371/journal. Pone.0001608.

[43] Menendez C, Ordi J, Ismail MR, Ventura PJ, Aponte JJ, Kahigwa E, Font F, Alonso PL: The impact of placental malaria on gestational age and birth weight. J Infect Dis 2000, 181:1740-1745.

[44] Calleja-Agius J \& Brincat, M.P. 2008. Recurrent Miscarriages: What is the Role of Cytokines? Gynecological Endocrinology. 24 (120). 663-668

[45] Darrasse-Je`ze, G., Klatzmann, D., Charlotte, F., Salomon, B.L., Cohen, J.L. 2006. CD4+CD25+ Regulatory/Suppressor T cells Prevent Allogeneic Fetus Rejection in Mice. Immunol Lett; 102:106-109 